\title{
Integrating Social Impact Assessment and Environmental Conflict Analysis on a Hydrocarbon Exploration Project in Spain
}

\author{
Alexi Delgado $^{\# *+1}$, I. Romero ${ }^{\# 2}$ \\ ${ }^{\#}$ Research Institute of Water and Environmental Engineering (IIAMA), \\ UniversitatPolitècnica de València. Camino de Vera s/n, 46022 Valencia, Spain. \\ ${ }^{1}$ kidelvil@doctor.upv.es \\ 2inrogi@dihma.upv.es \\ *Faculty of Science and Engineering, Universidad de Ciencias y Humanidades \\ Av. Universitaria 5175 - Lima 39 - Perú \\ ${ }^{+}$Specialty of environmental development, Universidad Nacional de Educación \\ Av. Enrique Guzmán y Valle s/n - Chosica - Lima - Perú \\ ${ }^{1}$ kidelvil@doctor.upv.es
}

\begin{abstract}
Social impact assessment (SIA) has become a key factor for environmental conflicts prevention, which makes necessary to integrate SIA and environmental conflict analysis (ECA). In this article, we integrate SIA and ECA using a method based on grey systems and Shannon entropy. A case study was conducted on a hydrocarbon exploration project located in the Sea of the Gulf of Valencia, Spain. Four stakeholder groups and four evaluation criteria were identified. The results revealed that for group of specialists the project would have negative social impact; and contrary perceptions were found between the group ofprimary activities populationand the group of retirees. It was also noted that the criteria most likely to generate environmental conflicts were the percentage of unemployment and the GDP per capita. These results could help central and community governments to make the best decision on the project. The method showed interesting results and could be apply to manage other projects or programs from point of view of social factors.
\end{abstract}

Keywords: SIA, ECA, Grey systems, Shannon entropy, Hydrocarbon exploration project.

\section{INTRODUCTION}

Social impact assessment (SIA) is an important factor to prevent environmental conflicts caused by implantation of investment projects on natural resources[1]. SIA has been mainly conducted by qualitative methods, as evidenced by studies based on public participation [2], or game theory [3].In this study, we apply a quantitative method for SIA: the grey clustering method (The GC method), which is based on grey systems theory.Moreover,SIA is characterized by its high level of uncertainty [4]. Therefore, SIA should be conducted by a method, which considers the uncertainly. The GC method is an approach that considers the uncertainty within its analysis, and also it enables the classification of observed objects into definable classes, called grey classes [5], as evidenced by the studies on a water rights allocation system [6], or the classification of innovation strategic alliances [7]. Grey systems theory,which was established by Julong Deng, focuses on the study of problems with small samples or limited information available [8]. In the real world, there are many uncertain systems with small samples or limited information, this fact determines a broad range of applicability of the grey systems. For example: geographical information systems [9], health management [10], optimization [11], or safety management [12].

In turn, environmental conflict analysis (ECA) also is a key factor to prevent conflicts during planning and implementation of projects and programs, as evidenced by the studies on conflicts related to ecological tourism [13], or water management [14], [15]. ECA has been mostly conducted using qualitative methods, as showed by the study on environmental conflict from an infrastructure project [1], which was based on the capability perspective. In this study, we apply a quantitative method for ECA: the entropy-weight method (the EW method), which is based on Shannon entropy theory. Shannon proposed the concept of entropy as a measure of uncertainty in information, formulated in terms of probability theory [16]. The concept of entropy is well suited to identify the contrast criteria for decision-making [17].Subsequent research on Shannon entropy has contributed to the resolution of problems in areas such as: pollution [18], water quality [19], management [20], or fault detection [21].

Furthermore, stakeholders are an important dimension for integrated assessment [22], and environmental conflicts are generated between stakeholder groups within affected population [23], [24]. Therefore, first SIA should be conducted for each stakeholder group, and then by ECA, the differences between them should be determined, in order to prevent possible environmental conflicts [1]. This fact makes that SIA and ECAshould be 
integrated. The combination of the GC method and the EW method could integrate SIA and ECA. First, the GC method assesses social impact by quantifying of information from stakeholder groups. And then, the EW method identifies criteria, for which, there is the most divergence between stakeholder groups within of project under scrutiny.

Subsequently, in order to apply and test the integrated method, we conducted a study of SIA and ECA on a hydrocarbon exploration project in the Sea of the Gulf of Valencia, Spain.This hydrocarbon exploration project consists of the application of ultrasound technology, in order to determine the existence of hydrocarbon deposits in the marine subsoil [25]. The company presented environmental impact assessment (EIA) to Spain government in 2012, but at the present (2016) this project is paused due to the fact that a part of the population of Valencia city manifests opposition to the implementation of the project.

The specific objectives of this article are to:

1. Integrate SIA and ECA using the GC method and the EW method.

2. Apply the integrated method to the concrete context of the hydrocarbon exploration project in the Sea of the Gulf of Valencia, Spain.

Section 2 provides details of the methodology to integrate SIA and ECA. In Section 3 the case study is described, followed by the results and discussion in Section 4. Conclusions are provided in Section 5.

\section{Methodology}

This section describes SIA using the GC method, ECA using the EW method, and provides the details of the integrated method for SIA and ECA.

\section{A. The GC method for SIA}

The GC method was developed to classify objects of observation into definable classes, and can be performed by means grey incidence matrices or whitenization weight functions. Whitenization weight functions are mainly used to test whether the objects of observation belong to predetermined classes. In this study, we use centerpoint triangular whitenization weight functions (CTWF), because typically people tend to be more certain about the center-points of grey classes in comparison with other points of the grey class. So, the conclusions based on this cognitive certainty could be more scientific and reliable [5].

The GC method based on CTWF can be described as follows [5], [7], [26]: first, assume that there are a set of $m$ objects, a set of $n$ criteria, and a set of s grey classes; according to the sample value $x_{i j}(i=1,2, \ldots, m ; j=1$, $2, \ldots, n)$. Then, the steps of the GC method based on CTWF can be developed as follows:

Step 1: The ranges of the criteria are divided into s grey classes, and then center-points $\lambda_{1}, \lambda_{2}, \ldots, \lambda_{\mathrm{s}}$ of grey classes $1,2, \ldots, \mathrm{s}$ are determined.

Step 2: The grey classes are expanded in two directions, adding the grey classes 0 and $(\mathrm{s}+1)$ with their centerpoints $\lambda_{0}$ and $\lambda_{s+1}$ respectively. The new sequence of center-points is $\lambda_{0}, \lambda_{1}, \lambda_{2}, \ldots, \lambda_{s}, \lambda_{s+1}$, see details in Fig. 1 . For the kth grey class, $\mathrm{k}=1,2, \ldots, \mathrm{s}$, of the $\mathrm{jth}$ criterion, $\mathrm{j}=1,2, \ldots, \mathrm{n}$, for an observed value $x_{i j}$, the CTWF is calculated by Eq. (1).

$$
f_{j}^{k}\left(x_{i j}\right)= \begin{cases}0, & x \notin\left[\lambda_{k-1}, \lambda_{k+1}\right] \\ \frac{x-\lambda_{k-1}}{\lambda_{k}-\lambda_{k-1}}, & x \in\left[\lambda_{k-1}, \lambda_{k}\right] \\ \frac{\lambda_{k+1}-x}{\lambda_{k+1}-\lambda_{k}}, & x \in\left[\lambda_{k}, \lambda_{k+1}\right]\end{cases}
$$

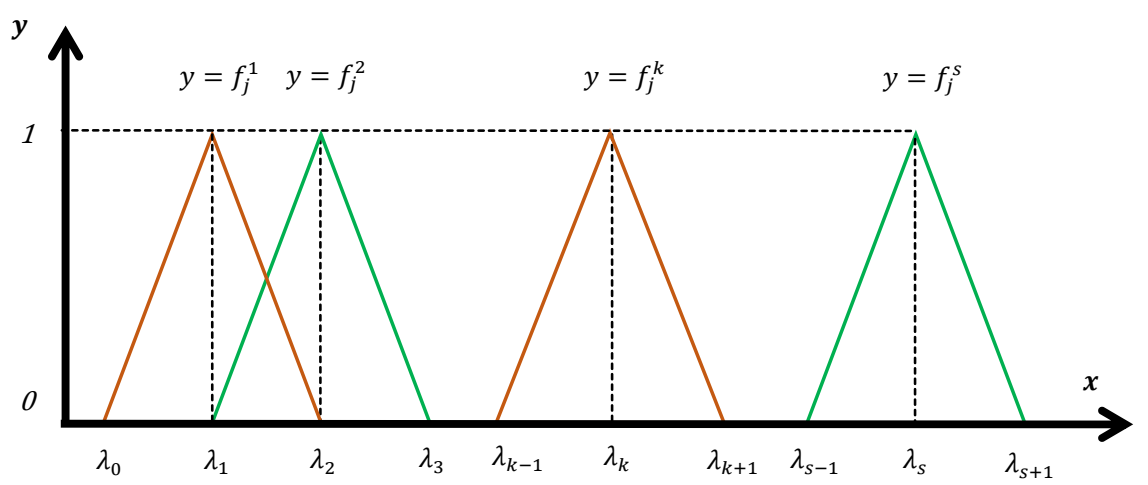

Fig. 1. CTWF [5] 
Step 3: The comprehensive clustering coefficient $\sigma_{i}^{k}$ for object $\mathrm{i}, \mathrm{i}=1,2, \ldots, \mathrm{m}$, with respect to the grey class $\mathrm{k}$, $\mathrm{k}=1,2, \ldots, \mathrm{s}$, is calculated by Eq. (2).

$$
\sigma_{i}^{k}=\sum_{j=1}^{n} f_{j}^{k}\left(x_{i j}\right) \cdot \eta_{j}
$$

where $f_{j}^{k}\left(x_{i j}\right)$ is the CTWF of the kth grey class of the jth criterion, and $\eta_{\mathrm{j}}$ is the weight of criterion $\mathrm{j}$.

Step 4:Ifmax $\operatorname{Iskss}_{1 \leq k}\left\{\sigma_{i}^{k}\right\}=\sigma_{i}^{k^{*}}$, we decide that object i belongs to grey class $\mathrm{k}^{*}$. When there are several objects in grey class $\mathrm{k}^{*}$, these objects can be ordered according to the magnitudes of their comprehensive clustering coefficients.

\section{B. The EW methodfor ECA}

The EW method can be developed as follows [26]-[28]: first, assume that there are $m$ objects for evaluation and $\mathrm{n}$ evaluation criteria, which form the decision matrix $Z=\left\{z_{i j} ; i=1,2, \ldots, m ; j=1,2, \ldots, n\right\}$. Then, the steps of the EW method can be expressed as follows:

Step 1: The decision matrix $Z=\left\{z_{i j} ; i=1,2, \ldots, m ; j=1,2, \ldots, n\right\}$ is normalized for each criterion $\mathrm{C}_{\mathrm{j}}(\mathrm{j}=1$, $2, \ldots, n)$. The normalized values $P_{\mathrm{ij}}$ are calculated by Eq. (3).

$$
P_{i j}=\frac{z_{i j}}{\sum_{i=1}^{m} z_{i j}}
$$

Step 2: The entropy $\mathrm{H}_{\mathrm{j}}$ of each criterion $\mathrm{C}_{\mathrm{j}}$ is calculated by Eq. (4).

$$
H_{j}=-k \sum_{i=1}^{m} P_{i j} \ln \left(P_{i j}\right)
$$

$\mathrm{k}$ is a constant, let $\mathrm{k}=(\ln (\mathrm{m}))^{-1}$.

Step 3: The degree of divergence div $v_{j}$ of each criterion $C_{j}$ is calculated by Eq. (5).

$$
\operatorname{div}_{j}=1-H_{j}
$$

Step 4: The entropy weight $\mathrm{w}_{\mathrm{j}}$ of each criterion $\mathrm{C}_{\mathrm{j}}$ is calculated by Eq.(6).

$$
w_{j}=\frac{d i v_{j}}{\sum_{j=1}^{n} d i v_{j}}
$$

\section{Integrating SIA and ECA}

The integrated method consists of five steps, of which the three first steps correspond to SIA, which are based on the GC method; and the two final steps correspond to ECA, which are based on the EW method, as shown in Fig. 2.

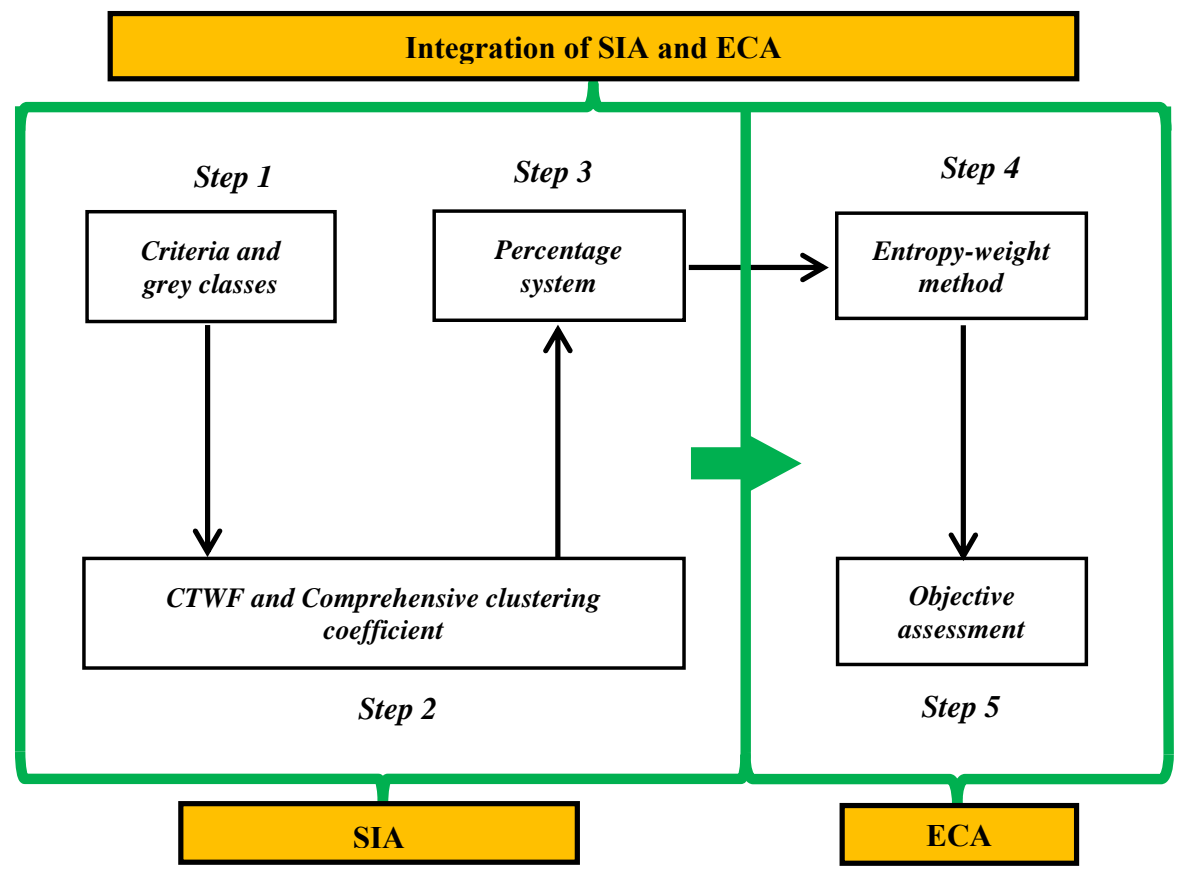

Fig. 2. Schema of the integration of SIA and ECA 
First, the integrated method can be described by means the following sets:

- A set of $\mathrm{m}$ stakeholder groups called $\mathrm{G}=\left\{\mathrm{G}_{1}, \mathrm{G}_{2}, \ldots, \mathrm{G}_{\mathrm{m}}\right\}$

- A set of $n$ criteria called $C=\left\{\mathrm{C}_{1}, \mathrm{C}_{2}, \ldots, \mathrm{C}_{\mathrm{n}}\right\}$

- A set of s grey classes called $\mathrm{V}=\left\{\mathrm{V}_{1}, \mathrm{~V}_{2}, \ldots, \mathrm{V}_{\mathrm{s}}\right\}$

- A set of evaluation values called $X=\left\{x_{i j}, i=1,2, \ldots, m ; j=1,2, \ldots, n\right\}$ of $G_{i}(i=1,2, \ldots, m)$ with respect to the criterion $C_{j}(j=1,2, \ldots, n)$

Then, the steps of the Integrated method are described as follows [26]:

Step 1:Criteria and grey classes

A set of $n$ criteria for SIA, determined by $C_{j}(j=1,2, \ldots, n)$, is established; and a set of $s$ grey classes, determined by $\mathrm{V}_{\mathrm{k}}(\mathrm{k}=1,2, \ldots, \mathrm{s})$, is defined.

\section{Step 2:CTWF and Comprehensive clustering coefficient}

The CTWF values of each stakeholder group are obtained using Eq. (1). Then, the comprehensive clustering coefficients $\sigma_{i}^{k}$ for object i, $\mathrm{i}=1,2, \ldots, \mathrm{m}$, with respect to the grey class $\mathrm{k}, \mathrm{k}=1, \ldots, \mathrm{s}$, are calculated using Eq. (2).

Step 3:Percentage system

SIA finishes with a percentage system [26], [29], defined by the values $\alpha_{1}, \alpha_{2}, \alpha_{3}, \ldots$, and $\alpha_{\mathrm{s}}$, where $\alpha_{\mathrm{s}}=100$, $\alpha_{1}=100 / \mathrm{s}, \alpha_{2}=\alpha_{1}+\alpha_{1}, \alpha_{3}=\alpha_{1}+\alpha_{2}, \ldots$, and $\alpha_{\mathrm{s}-1}=\alpha_{1}+\alpha_{\mathrm{s}-2} ; \mathrm{s}$ is the number of grey classes defined. The results for each stakeholder group are given by Eq. (7).

$$
z_{j}^{i}=\sum_{k=1}^{s} f_{j}^{k}\left(x_{i j}\right) \cdot \alpha_{k}
$$

where $f_{j}^{k}\left(x_{i j}\right)$ is CTWF of the kth grey class of the jth criterion and $\alpha_{k}$ is the percentage value of each grey class. The results are represented by the matrix determined by Eq. (8).

$$
Z=z_{j}^{i}=\left\{z_{i j}, i=1,2, \ldots, m ; j=1,2, \ldots, n\right\}
$$

Step 4:Entropy-weight method

ECA is carried out by applying the EW method. First, using Eq. (3). The normalized values $\mathrm{P}_{\mathrm{ij}}$ of the matrix $Z=z_{j}^{i}=\left\{z_{i j}, i=1,2, \ldots, m ; j=1,2, \ldots, n\right\}$ are calculated. Then, $\mathrm{H}_{\mathrm{j}}$, div $\mathrm{di}_{\mathrm{j}}$ and $\mathrm{w}_{\mathrm{j}}$ are determined using Eqs. (4)(6).

\section{Step 5:Objective assessment}

The final step of ECA involves calculating the objective assessment [20], [26] of each stakeholder group i, $\mathrm{i}=1,2, \ldots, \mathrm{m}$, for each criterion $\mathrm{C}_{\mathrm{j}}(\mathrm{j}=1,2, \ldots, \mathrm{n})$. The objective assessment value is defined by Eq. (9).

$$
Q_{i j}=w_{j} z_{i j}
$$

where $w_{j}$ is the entropy weight for each criterion $\mathrm{C}_{\mathrm{j}}$ and $z_{i j}$ is the result of SIA for each stakeholder group. The results are represented by the matrix defined by Eq. (10).

$$
Q_{i j}=\left[\begin{array}{cccc}
w_{1} z_{11} & w_{2} z_{12} & \ldots & w_{n} z_{1 n} \\
w_{1} z_{21} & w_{2} z_{22} & \ldots & w_{n} z_{2 n} \\
\vdots & \vdots & \ddots & \vdots \\
w_{1} z_{m 1} & w_{2} z_{m 2} & \ldots & w_{n} z_{m n}
\end{array}\right]
$$

\section{III.CASE STUDY}

SIA and ECA were performed for a project located in the Sea of the Gulf of Valencia in Spain, as shown in Fig. 3. The concerned company proposes to conduct the hydrocarbon exploration by means a campaign of 3D seismic acquisition in zones $\mathrm{B}, \mathrm{G}, \mathrm{AM}-1$ and AM-2, indicated on the map [25]. Ultrasound technology was proposed to be used to determine the existence of hydrocarbon deposits in the marine subsoil. This study was conducted on the city of Valencia, located into the zone of influence of the project. 


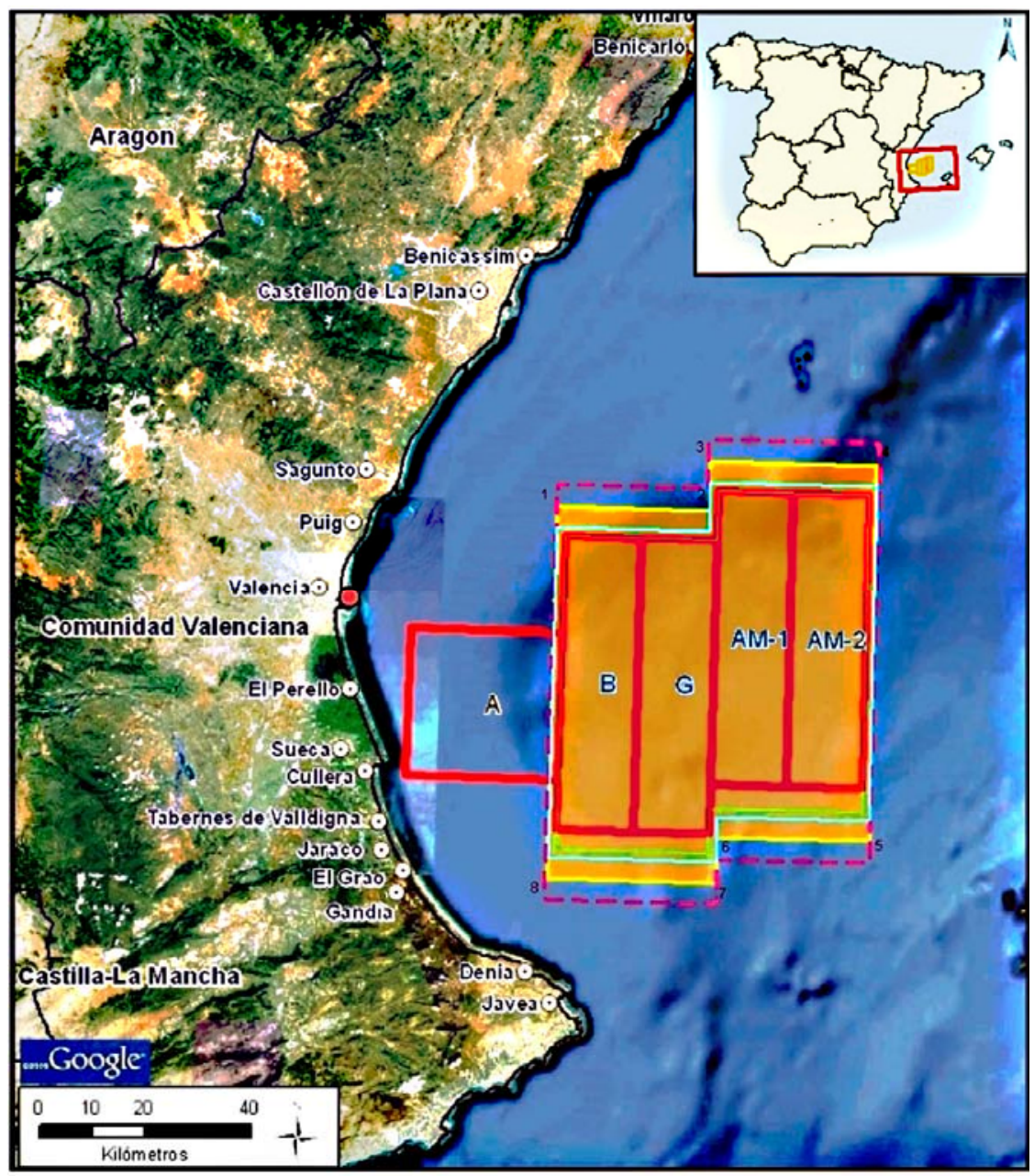

Fig. 3. Project location[25]

\section{A. Stakeholder Groups}

During the field work, we identified four different stakeholder groups $(\mathrm{k}=4)$, the composition of these groups was determined according to similarities found during the overall assessment on the hydrocarbon exploration project [26]. The sample size in each group was determined by means the principle of saturation of discourse, which establish that information gathering should end when respondents do not produce new information relevant to object of study [30]. The stakeholder groups are presented in Table I:

TABLE I. Stakeholder groups in the case study

\begin{tabular}{|l|l|}
\hline Stakeholder group & \multicolumn{1}{c|}{ Description } \\
\hline $\begin{array}{l}\text { G1: Primary } \\
\text { activities population }\end{array}$ & $\begin{array}{l}\text { It was composed of those members of the population who are directly linked with the } \\
\text { impacts of the project, consisting of people undertaking productive activities related to } \\
\text { fishing or tourism (see Fig. 4). This group was made up of thirty interviewees. }\end{array}$ \\
\hline $\begin{array}{l}\text { G2: University } \\
\text { students }\end{array}$ & $\begin{array}{l}\text { It was composed of students with no links to productive activities related to fishing or } \\
\text { tourism (see Fig. 5). This group was made up of thirty interviewees. }\end{array}$ \\
\hline G3: Retirees & It was composed of retirees (see Fig. 6). This group was made up of fifteen interviewees. \\
\hline G4: Specialists & $\begin{array}{l}\text { It was composed of experts from different fields who are familiar with the area of } \\
\text { influence and the characteristics of the environmental and social impacts of hydrocarbon } \\
\text { exploration projects (see Fig. 7). This group was made up of eight interviewees. }\end{array}$ \\
\hline
\end{tabular}




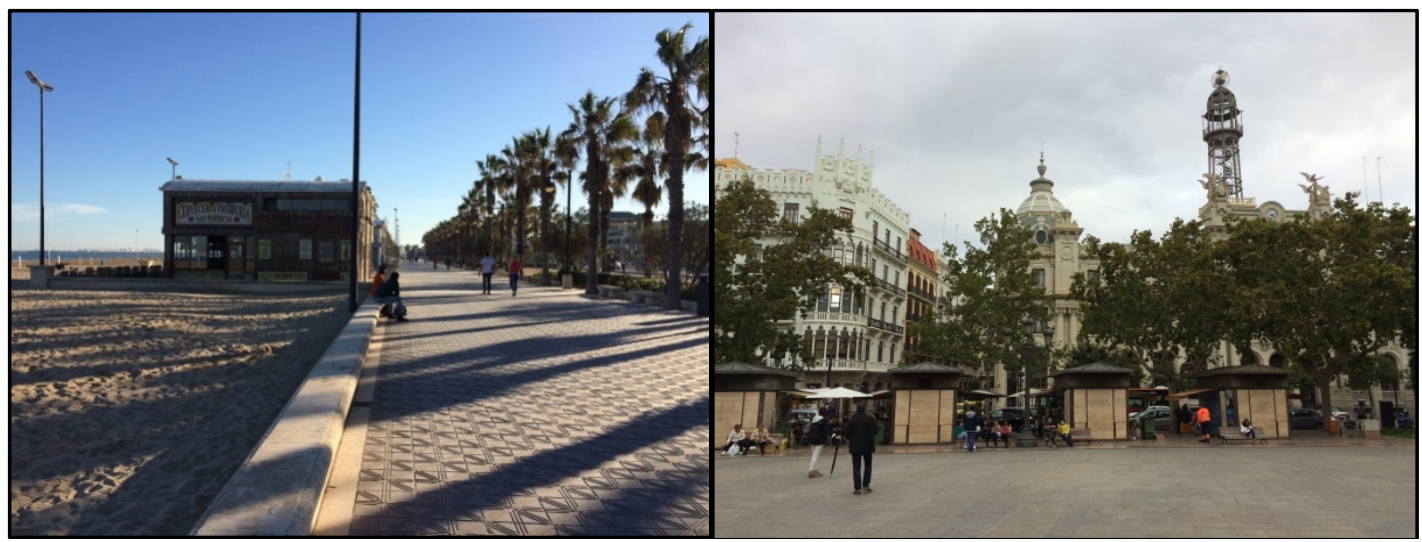

Fig. 4. Directly affected populationFig. 5. University students

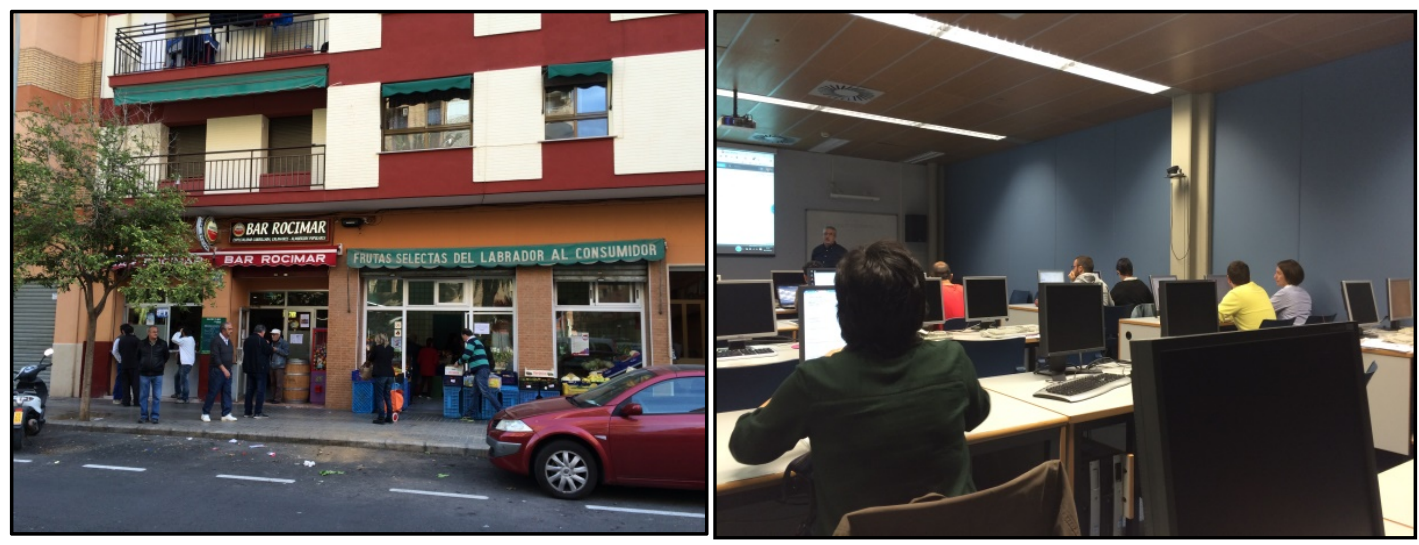

Fig. 6. RetireesFig. 7. Specialists

\section{B. Calculations using the integrated method}

The calculations for the case study, based on the integrated method, are preceded as follows.

Step 1: Criteria and grey classes

a. Evaluation criteria

The criteria for the case study were established by taking into account to the economic and social situation of the city of Valencia and the characteristics of the project, and by consulting with experts. The social criteria are directly linked to the economic criteria, due to the fact that social conflicts in Spain are related to the economic crisis facing the country. Four criteria $(n=4)$ were identified as shown in Fig. 8.

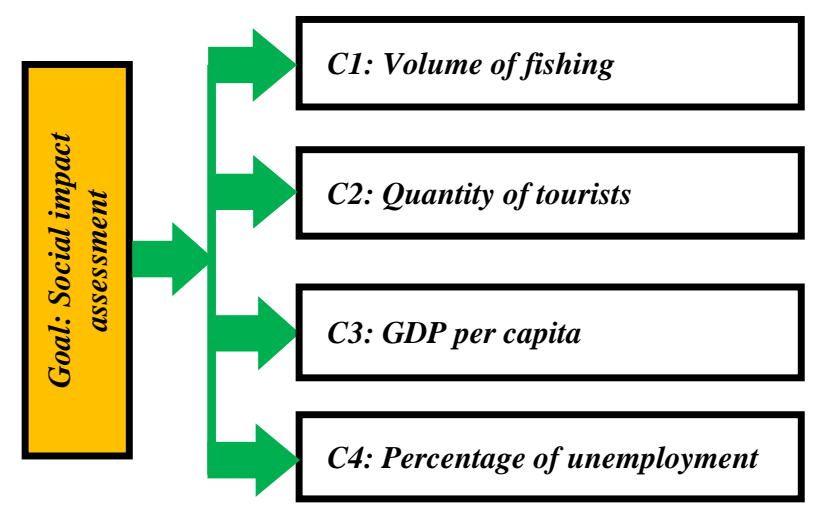

Fig. 8. Criteria system of the case study

The established criteria are described in Table II. 
TABLE II. Evaluation criteria in the case study

\begin{tabular}{|c|l|}
\hline Criterion & \multicolumn{1}{c|}{ Description } \\
\hline $\mathrm{C} 1$ & $\begin{array}{l}\text { It measured the change in the volume of fishing in the ComunitatValenciana, with the baseline } \\
\text { figure being taken as the volume of fishing in 2013, which was 31,29 thousand tonnes of fish } \\
{[31] .}\end{array}$ \\
\hline C2 & $\begin{array}{l}\text { It measured the change in the number of foreign tourists visiting the ComunitatValenciana, } \\
\text { with the baseline figure being taken as the number of foreign tourists in 2013, which was 5.97 } \\
\text { million [31]. }\end{array}$ \\
\hline C3 & $\begin{array}{l}\text { It measured the change in quantity of GDP per capita in the ComunitatValenciana, with the } \\
\text { baseline figure being the GDP per capita in 2013, which was 19,500 euros per year [32]. }\end{array}$ \\
\hline C4 & $\begin{array}{l}\text { It measured the change in the percentage of unemployment in the ComunitatValenciana, with } \\
\text { the baseline figure being the unemployment rate in 2013, which was 28.05\% [31]. }\end{array}$ \\
\hline
\end{tabular}

b. Grey classes

Five grey classes $(\mathrm{s}=5)$ for the case study were established according to the historical information from 2009 to 2013 [31], [32], and by the consultation with experts, in order to satisfy the need to reflect the characteristics of the specific region as accurately as possible [5]. All the criteria had the same weight $\left(\eta_{j}=0.250\right)$, as they are social criteria [30]. The grey classes established for each criterion are shown in Table III.

TABLE III. Grey classes for each criterion in the case study

\begin{tabular}{|c|c|c|c|c|c|}
\hline \multirow[b]{2}{*}{ Criterion } & \multicolumn{5}{|c|}{ Grey classes } \\
\hline & $\begin{array}{c}\text { Very } \\
\text { Negative (V1) }\end{array}$ & Negative (V2) & Normal (V3) & Positive (V4) & $\begin{array}{c}\text { Very } \\
\text { Positive (V5) }\end{array}$ \\
\hline $\mathrm{C} 1$ & $\begin{array}{l}25.07 \leq \mathrm{x}_{1}^{1} \leq \\
27.56\end{array}$ & $\begin{array}{l}27.56 \leq \mathrm{x}_{1}^{2} \leq \\
30.05\end{array}$ & $\begin{array}{l}30.05 \leq x_{1}^{3} \leq \\
32.54\end{array}$ & $\begin{array}{l}32.54 \leq \mathrm{x}_{1}^{4} \leq \\
35.03\end{array}$ & $\begin{array}{l}35.03 \leq \mathrm{x}_{1}^{5} \leq \\
37.52\end{array}$ \\
\hline $\mathrm{C} 2$ & $\begin{array}{l}04.78 \leq \mathrm{x}_{2}^{1} \leq \\
05.26\end{array}$ & $\begin{array}{l}05.26 \leq x_{2}^{2} \leq \\
05.73\end{array}$ & $\begin{array}{l}05.73 \leq x_{2}^{3} \leq \\
06.21\end{array}$ & $\begin{array}{l}06.21 \leq \mathrm{x}_{2}^{4} \leq \\
06.68\end{array}$ & $06.68 \leq \mathrm{x}_{2}^{5} \leq$ \\
\hline $\mathrm{C} 3$ & $\begin{array}{l}18.66 \leq x_{3}^{1} \leq \\
19.00\end{array}$ & $\begin{array}{l}19.00 \leq x_{3}^{2} \leq \\
19.33\end{array}$ & $\begin{array}{l}19.33 \leq x_{3}^{3} \leq \\
19.67\end{array}$ & $\begin{array}{l}19.67 \leq \mathrm{x}_{3}^{4} \leq \\
20.00\end{array}$ & $\begin{array}{l}20.00 \leq x_{3}^{5} \leq \\
20.34\end{array}$ \\
\hline $\mathrm{C} 4$ & $\begin{array}{l}33.52 \leq \mathrm{x}_{4}^{1} \leq \\
37.16\end{array}$ & $\begin{array}{l}29.87 \leq \mathrm{x}_{4}^{2} \leq \\
33.52\end{array}$ & $\begin{array}{l}26.23 \leq \mathrm{x}_{4}^{3} \leq \\
29.87\end{array}$ & $\begin{array}{l}22.58 \leq \mathrm{x}_{4}^{4} \leq \\
26.23\end{array}$ & $\begin{array}{l}18.94 \leq \mathrm{x}_{4}^{5} \leq \\
22.58\end{array}$ \\
\hline
\end{tabular}

Step 2: CTWF and the comprehensive clustering coefficient

The data obtained from the stakeholder groups were processed using CTWF. The grey classes were extended in two directions by adding the grey classes $\mathrm{V}_{0}$ and $\mathrm{V}_{6}$ ("extra negative" and "extra positive", respectively), with their center-points $\lambda_{0}$ and $\lambda_{6}$. Therefore, the new sequence of center-points was $\lambda_{0}, \lambda_{1}, \lambda_{2}, \lambda_{3}$, and $\lambda_{6}$, as shown in Table IV and Fig. 9.

Table IV. Center-points of the extended grey classes in the case study

\begin{tabular}{|c|c|c|c|c|c|c|c|}
\hline & \multicolumn{7}{|c|}{ Center-points of the extended grey classes } \\
\cline { 2 - 8 } Criterion & $\begin{array}{c}\text { Extra } \\
\text { negative } \\
\text { impact } \\
\left(\boldsymbol{\lambda}_{\mathbf{0}}\right)\end{array}$ & $\begin{array}{c}\text { Very } \\
\text { negative } \\
\text { impact } \\
\left(\boldsymbol{\lambda}_{\mathbf{1}}\right)\end{array}$ & $\begin{array}{c}\text { Negative } \\
\text { impact }\left(\boldsymbol{\lambda}_{\mathbf{2}}\right)\end{array}$ & $\begin{array}{c}\text { Normalimpact } \\
\left(\boldsymbol{\lambda}_{\mathbf{3}}\right)\end{array}$ & $\begin{array}{c}\text { Positive } \\
\text { impact } \\
\left(\boldsymbol{\lambda}_{\mathbf{4}}\right)\end{array}$ & $\begin{array}{c}\text { Very } \\
\text { positive } \\
\text { impact } \\
\left(\boldsymbol{\lambda}_{\mathbf{5}}\right)\end{array}$ & $\begin{array}{c}\text { Extra } \\
\text { positive } \\
\text { impact } \\
\left(\boldsymbol{\lambda}_{\mathbf{6}}\right)\end{array}$ \\
\hline $\mathrm{C} 1$ & 23.82 & 26.31 & 28.80 & 31.29 & 33.78 & 36.27 & 38.76 \\
\hline $\mathrm{C} 2$ & 04.55 & 05.02 & 05.50 & 05.97 & 06.45 & 06.92 & 07.40 \\
\hline $\mathrm{C} 3$ & 18.50 & 18.83 & 19.17 & 19.50 & 19.84 & 20.17 & 20.51 \\
\hline $\mathrm{C} 4$ & 38.99 & 35.34 & 31.70 & 28.05 & 24.41 & 20.76 & 17.12 \\
\hline
\end{tabular}




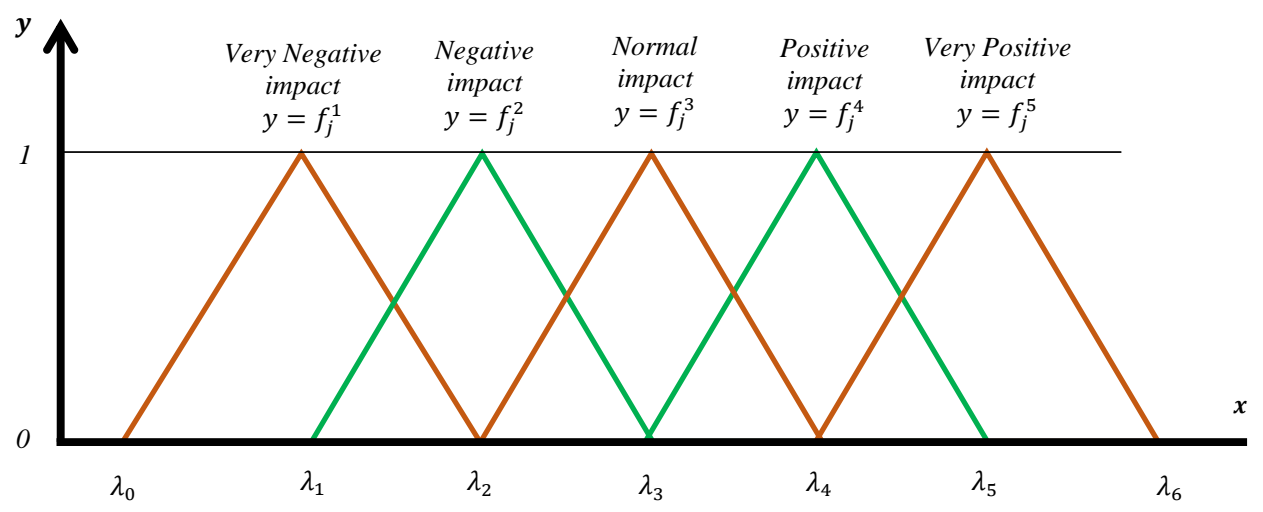

Fig. 9. CTWF for the case study

As illustration, for the first criterion $\mathrm{C} 1 \mathrm{j}=1)$ shown in the first row of Table III and Table IV, we have the grey classes: $\mathrm{V}_{1}=[25.07 ; 27.56], \mathrm{V}_{2}=[27.56 ; 30.05], \mathrm{V}_{3}=[30.05 ; 32.54], \mathrm{V}_{4}=[32.54 ; 35.03]$, and $\mathrm{V}_{5}=[35.03$; 37.52]; with their center-points: $\lambda_{1}=26.31, \lambda_{2}=28.80, \lambda_{3}=31.29, \lambda_{4}=33.78$, and $\lambda_{5}=36.27$. The grey classes were then expanded in two directions by adding the grey classes $\mathrm{V}_{0}=[22.58 ; 25.07]$ and $\mathrm{V}_{6}=[37.52 ; 40.01]$, with their centres $\lambda_{0}=23.82$ and $\lambda_{6}=38.76$. Thus, we obtained a new sequence of centres: $\lambda_{0}, \lambda_{1}, \lambda_{2}, \lambda_{3}$, and $\lambda_{6}$. The values were substituted into Eq. (1), to obtain the CTWF of the five grey classes. The results for the first criterion $\mathrm{C} 1$ are shown in Eqs. (11)-(15):

$$
\begin{aligned}
& f_{1}^{1}(x)= \begin{cases}\frac{0,}{\frac{x-23.82}{2.49},}, & x \notin[23.82,28.80] \\
\frac{28.80-x}{2.49}, & x \in[23.82,26.31]\end{cases} \\
& f_{1}^{2}(x)= \begin{cases}\frac{0,}{x-26.31} & x \notin[26.31,31.29] \\
\frac{31.29-x}{2.49}, & x \in[26.31,28.80] \\
& x \in[28.80,31.29]\end{cases} \\
& f_{1}^{3}(x)= \begin{cases}\frac{0,}{x-28.80} & x \notin[28.80,33.78] \\
\frac{33.78-x}{2.49}, & x \in[28.80,31.29]\end{cases} \\
& f_{1}^{4}(x)= \begin{cases}\frac{x-31.29}{2.49}, & x \notin[31.29,36.27] \\
\frac{36.27-x}{2.49}, & x \in[31.29,33.78]\end{cases} \\
& f_{1}^{5}(x)= \begin{cases}\frac{0,}{\frac{x-33.78}{2.49},}, & x \notin[33.78,38.76] \\
\frac{38.76-x}{2.49}, & x \in[33.78,36.27]\end{cases}
\end{aligned}
$$

The information from stakeholder groups was gathered by means of direct interviews using a structured questionnaire based on the evaluation criteria and grey classes established for the case study. The questions used are presented in Table V. 
TABLE V. Questions used in the questionnaire for the case study

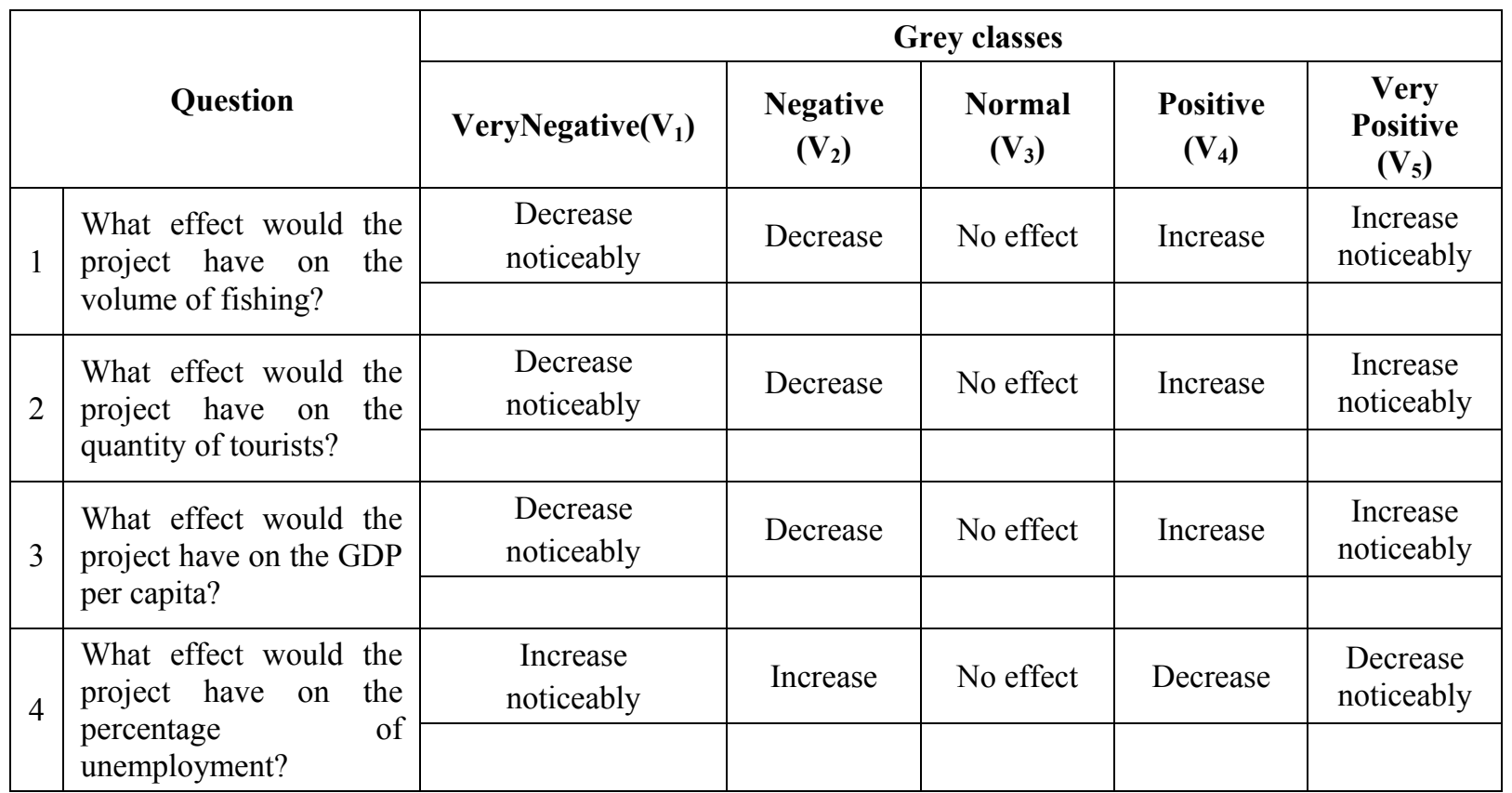

Table VI shows the overall results of evaluation from four stakeholder groups $(\mathrm{m}=4)$ for each criterion. These data were aggregated using the arithmetic mean [33].

TABLE VI. Aggregated values of each criterion for groups G1, G2, G3 and G4

\begin{tabular}{|c|c|c|c|c|}
\hline Group & C1 & C2 & C3 & C4 \\
\hline G1 & 26.81 & 05.16 & 18.85 & 34.98 \\
\hline G2 & 26.89 & 05.59 & 19.53 & 26.96 \\
\hline G3 & 30.13 & 05.88 & 19.92 & 22.22 \\
\hline G4 & 27.87 & 05.61 & 19.42 & 27.14 \\
\hline
\end{tabular}

Then, for group G1, the values of CTWF were calculated using Eqs. (11)-(15). Subsequently, the comprehensive clustering coefficient $\left(\sigma_{i}^{k}\right)$ was calculated for each stakeholder group using Eq. (2). The values of CTWF and $\sigma_{i}^{k}$ obtained for group G1 $(\mathrm{m}=1)$ are shown in Table VII.

TABLE VII. Values of CTWF and $\boldsymbol{\sigma}_{\boldsymbol{i}}^{\boldsymbol{k}}$ for group G1

\begin{tabular}{|c|c|c|c|c|c|}
\hline $\boldsymbol{f}_{\boldsymbol{j}}^{\boldsymbol{k}}(\boldsymbol{x})$ & $\mathbf{C 1}$ & $\mathbf{C 2}$ & $\mathbf{C 3}$ & $\mathbf{C 4}$ & $\boldsymbol{\sigma}_{\boldsymbol{i}}^{\boldsymbol{k}}$ \\
\hline $\boldsymbol{f}_{\boldsymbol{j}}^{\mathbf{0}}(\boldsymbol{x})$ & 0.8000 & 0.7000 & 0.9333 & 0.9000 & 0.8333 \\
\hline $\boldsymbol{f}_{\boldsymbol{j}}^{\mathbf{1}}(\boldsymbol{x})$ & 0.2000 & 0.3000 & 0.0667 & 0.1000 & 0.1667 \\
\hline $\boldsymbol{f}_{\boldsymbol{j}}^{\mathbf{2}}(\boldsymbol{x})$ & 0.0000 & 0.0000 & 0.0000 & 0.0000 & 0.0000 \\
\hline $\boldsymbol{f}_{\boldsymbol{j}}^{\mathbf{3}}(\boldsymbol{x})$ & 0.0000 & 0.0000 & 0.0000 & 0.0000 & 0.0000 \\
\hline $\boldsymbol{f}_{\boldsymbol{j}}^{\mathbf{4}}(\boldsymbol{x})$ & 0.0000 & 0.0000 & 0.0000 & 0.0000 & 0.0000 \\
\hline
\end{tabular}

Step 3: Percentage system

The final stage of SIA for the case study involved the employment of a percentage system defined by the values $\alpha_{1}, \alpha_{2}, \alpha_{3}, \alpha_{4}$, and $\alpha_{5}$; where $\alpha_{5}=100, \alpha_{1}=100 / 5=20, \alpha_{2}=\alpha_{1}+\alpha_{1}=40, \alpha_{3}=\alpha_{1}+\alpha_{2}=60$, and $\alpha_{4}=\alpha_{1}+\alpha_{3}=80$; according to five grey classes established, as shown in Table VIII. Then, SIA for group G1 was calculated using Eq. (7). The results are presented in Table IX. 
TABLE VIII. The percentage system determined in the case study

\begin{tabular}{|c|c|c|}
\hline Impact class & Interval & $\boldsymbol{\alpha}_{\mathbf{k}}$ \\
\hline Very negative & {$[20,30]$} & 20 \\
\hline Negative & {$[30,50]$} & 40 \\
\hline Normal & {$[50,70]$} & 60 \\
\hline Positive & {$[70,90]$} & 80 \\
\hline Very positive & {$[90,100]$} & 100 \\
\hline
\end{tabular}

TABLE IX. Results of SIA for group G1

\begin{tabular}{|c|c|c|c|c|c|c|}
\hline Impact class & $\boldsymbol{\alpha}_{\mathbf{k}}$ & $\mathbf{C 1}$ & $\mathbf{C 2}$ & $\mathbf{C 3}$ & $\mathbf{C 4}$ & Total \\
\hline Very negative & 20 & 16.00 & 14.00 & 18.67 & 18.00 & 16.67 \\
\hline Negative & 40 & 08.00 & 12.00 & 02.67 & 04.00 & 06.67 \\
\hline Normal & 60 & 00.00 & 00.00 & 00.00 & 00.00 & 00.00 \\
\hline Positive & 80 & 00.00 & 00.00 & 00.00 & 00.00 & 00.00 \\
\hline Very positive & 100 & 00.00 & 00.00 & 00.00 & 00.00 & 00.00 \\
\hline & \multirow{2}{*}{ SIA } & 24.00 & 26.00 & 21.33 & 22.00 & 23.33 \\
\cline { 2 - 7 } & & $\begin{array}{c}\text { Very } \\
\text { negative }\end{array}$ & $\begin{array}{c}\text { Very } \\
\text { Negative }\end{array}$ & $\begin{array}{c}\text { Very } \\
\text { negative }\end{array}$ & $\begin{array}{c}\text { Very } \\
\text { negative }\end{array}$ & $\begin{array}{c}\text { Very } \\
\text { negative }\end{array}$ \\
\hline
\end{tabular}

The values of SIA for groups G2, G3 and G4 were obtained using the same procedure as for group G1. The results for all stakeholder groups are presented in Table X.

TABLE X. Results of SIA for groups G1, G2, G3 and G4

\begin{tabular}{|c|c|c|c|c|c|c|}
\hline Group & C1 & C2 & C3 & C4 & Total & Impact class \\
\hline G1 & 24.00 & 26.00 & 21.33 & 22.00 & 23.33 & Very negative \\
\hline G2 & 24.67 & 44.00 & 62.00 & 66.00 & 49.17 & Negative \\
\hline G3 & 50.67 & 56.00 & 85.33 & 92.00 & 71.00 & Positive \\
\hline G4 & 32.50 & 45.00 & 55.00 & 65.00 & 49.38 & Negative \\
\hline
\end{tabular}

Step 4: Entropy-weight method

ECA for the case study was carried out by applying the EW method. First, the criteria values shown in Table $X$ were normalized using Eq. (3). The normalized values are shown in Table XI. Then, $H_{j}, \operatorname{div}_{j}$, andw a were $_{j}$ calculated using Eqs. (4)-(6). The results are shown in Table XII.

TABLE XI. Normalized results of SIA for groups G1, G2, G3 and G4

\begin{tabular}{|c|c|c|c|c|}
\hline Group & C1 & C2 & C3 & C4 \\
\hline G1 & 0.182 & 0.152 & 0.095 & 0.090 \\
\hline G2 & 0.187 & 0.257 & 0.277 & 0.269 \\
\hline G3 & 0.384 & 0.327 & 0.382 & 0.376 \\
\hline G4 & 0.247 & 0.263 & 0.246 & 0.265 \\
\hline
\end{tabular}

TABLE XII. Values of $\mathrm{H}_{\mathrm{j}}, \operatorname{div}_{\mathrm{j}}$ and $\mathrm{w}_{\mathrm{j}}$ for each criterion

\begin{tabular}{|c|c|c|c|c|}
\hline & C1 & C2 & C3 & C4 \\
\hline $\boldsymbol{H}_{\boldsymbol{j}}$ & 0.964 & 0.976 & 0.932 & 0.930 \\
\hline $\boldsymbol{d i v}_{\boldsymbol{j}}$ & 0.036 & 0.024 & 0.068 & 0.070 \\
\hline $\boldsymbol{w}_{\boldsymbol{j}}$ & 0.182 & 0.123 & 0.343 & 0.353 \\
\hline
\end{tabular}

Step 5: Objective assessment

ECA for the case study was completed by calculating objective assessment of each stakeholder group i, i=1, 2, 3 , 4, for each criterion $C_{j}(j=1,2,3,4)$. The results were obtained using Eq. (9), as shown in Table XIII. 
TABLE XIII. Objective assessment scores for each group

\begin{tabular}{|c|c|c|c|c|}
\hline Group & C1 & C2 & C3 & C4 \\
\hline G1 & 04.36 & 03.20 & 07.31 & 07.76 \\
\hline G2 & 04.48 & 05.41 & 21.24 & 23.28 \\
\hline G3 & 09.21 & 06.89 & 29.23 & 32.45 \\
\hline G4 & 05.91 & 05.53 & 18.84 & 22.92 \\
\hline
\end{tabular}

IV.RESULTS AND DISCUSSION

The results and discussion, according to objectives in this study, are presented below.

\section{A. The potential of the integrated method to SIA and ECA}

First, SIA is a topic with high level of uncertainty; therefore, it should be analysed by methods, which consider the uncertainty. Some classical approaches of multi-criteria analysis, such as Delphi [34], [35] or analytic hierarchy process (AHP) [36], [37], do not consider the uncertainty within their analysis, due to the fact that the importance degrees of criteria and performance scores of alternatives are assumed to be known precisely [38]. In addition, some options to model the uncertainly can be fuzzy logic approaches [39], probabilistic approaches [40] or grey systems approaches [5].

Second, Approaches based on fuzzy logic, such as fuzzy analytic hierarchy process (FAHP) [39], [41], emphasize the investigation of problems with cognitive uncertainty, which research objects possess the characteristic of clear intention and unclear extension. The focus of approaches based on grey systems theory is on the uncertainty problems, which the research objects possess the characteristic of unclear intention and clear extension [5]. SIA has clear extension of the criteria on a study determined; for example, in a historic range of five years, we can know the minimum and maximum value of a social variable under analysis. In addition, affected population of a determined project could be clear about when things were good or bad: before or after project implementation [26].

Third, in statistical approaches the concept of large samples represents the degree of tolerance to incompleteness [5], and considering that one of the criteria for evaluating methods can be the cost [4], in this aspect an approach based in grey systems would have a lower cost with respect to a statistical approach, due to the fact that sample size influences on the cost during the field work. In addition, in 1994, JiangpingQiu and Xisheng Hua established a comparison between statistical regression model and grey model on the deformation and leakage data of a certain large scale hydraulic dam. Their work showed that their grey model could provide a better fit than the statistical regression model [5].

Therefore, it could be argued that the GC method based on grey systems theory would benefit SIA, as it considers the uncertainty within its analysis. In addition, the grey clustering method would be more adequate than approaches based on fuzzy logic, as it considers clear extension for evaluation criteria. Furthermore, the GC method could be more effective and would have a lower cost than other statistical approaches during its application.

In turn, ECA is a social topic, which also has high level of uncertainty. ECA could be conducted by classical multi-criteria methods [4], or by statistical approaches [5]. However, classical multi-criteria methods do not consider the uncertainty within their analysis [38]. In addition, statistical approaches would have high cost during the field work [4]. ECA could be carried out by means the EW method based on Shannon entropy, which is a method that also considers the uncertainty within its analysis [17]. Therefore, the EW method and the GC methodare a good option to integrate SIA and ECA,both under the same philosophy.

\section{B. The case study}

\section{Analysis of findings from calculations}

The calculations for the case study produced three important findings, which are discussed below.

First, the major tensions among stakeholder groups were identified. Fig. 10 (based on Table X) shows a strong antagonism between groups G1 (primary activities population) and G3 (retirees), despite the fact that the specialists (G4) expressed the opinion that the project would have a negative social impact. The results indicate that G1 and G3, presented contradictory views on the project, these differences suggest potential conflicts between G1 and G3 groups. In order to analyse and more fully understand the mechanisms and forces at play, we need to look at the specific criteria of conflict between G1 and G3, which points to our second important finding. 


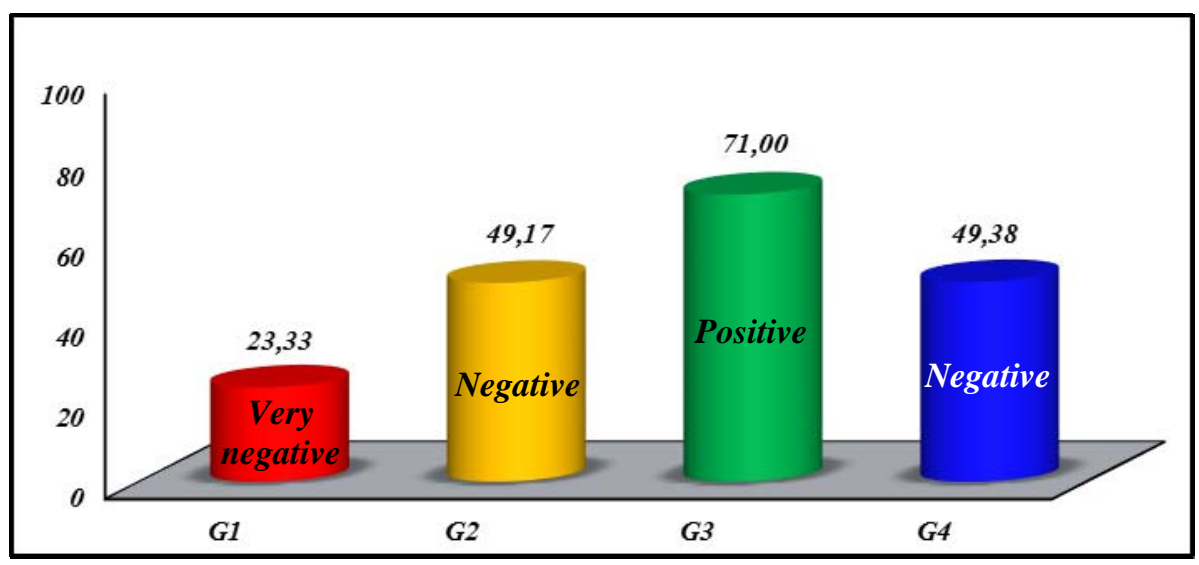

Fig. 10. Values of SIA of each group

Second, Figure 11 based on Table X shows the behaviour of the criteria for G1 and G3 groups: for group G1, all the criteria are in the "very negative" range; for group G3, C1 and C2 are placed in the range of "normal", C3 is found in the range of "positive", and $\mathrm{C} 4$ is in the range of "very positive". These results suggest a specific comparison of all these criteria, in order to identify the most controversial criteria among them.

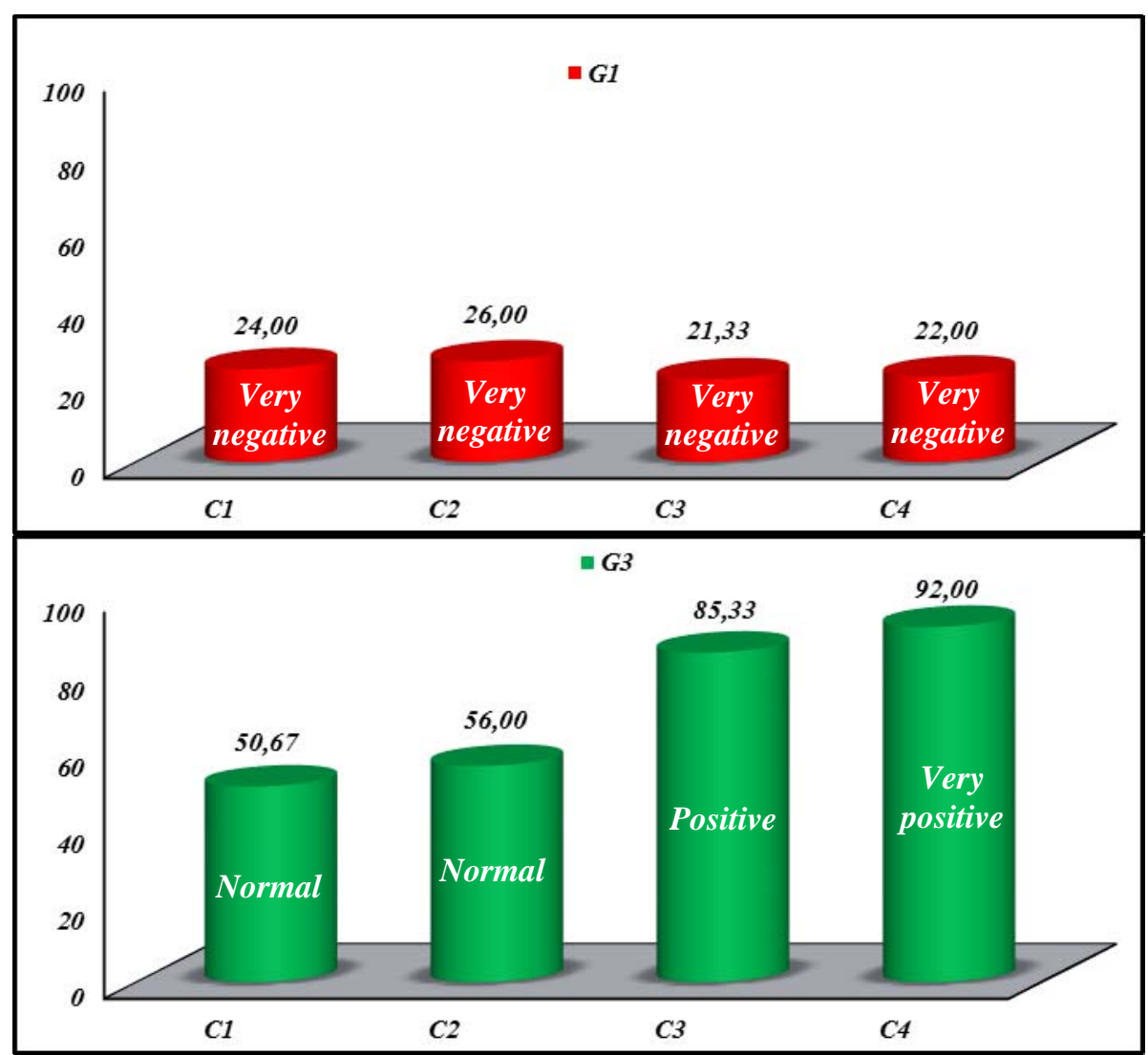

Fig. 11. Values of SIA of each criterion for groups G1 and G3

Third, the most divergent criteria between the stakeholder groups, which could imply potential causes of conflicts, were identified. Fig. 12, which is based on Table XIII, shows that the stakeholder groups converge for criteria C1 (volume of fishing) and C2 (quantity of tourists) and diverge for criteria C3 (GDP per capita) and C4 (percentage of unemployment). The convergent criteria can be considered as strengths and the divergent criteria as threats in a possible environmental conflict. The criterion with the greatest divergence is related to unemployment, followed by GDP per capita. Therefore, these issues should be taken into account when implementing measures to prevent environmental conflicts on the hydrocarbon exploration project. 


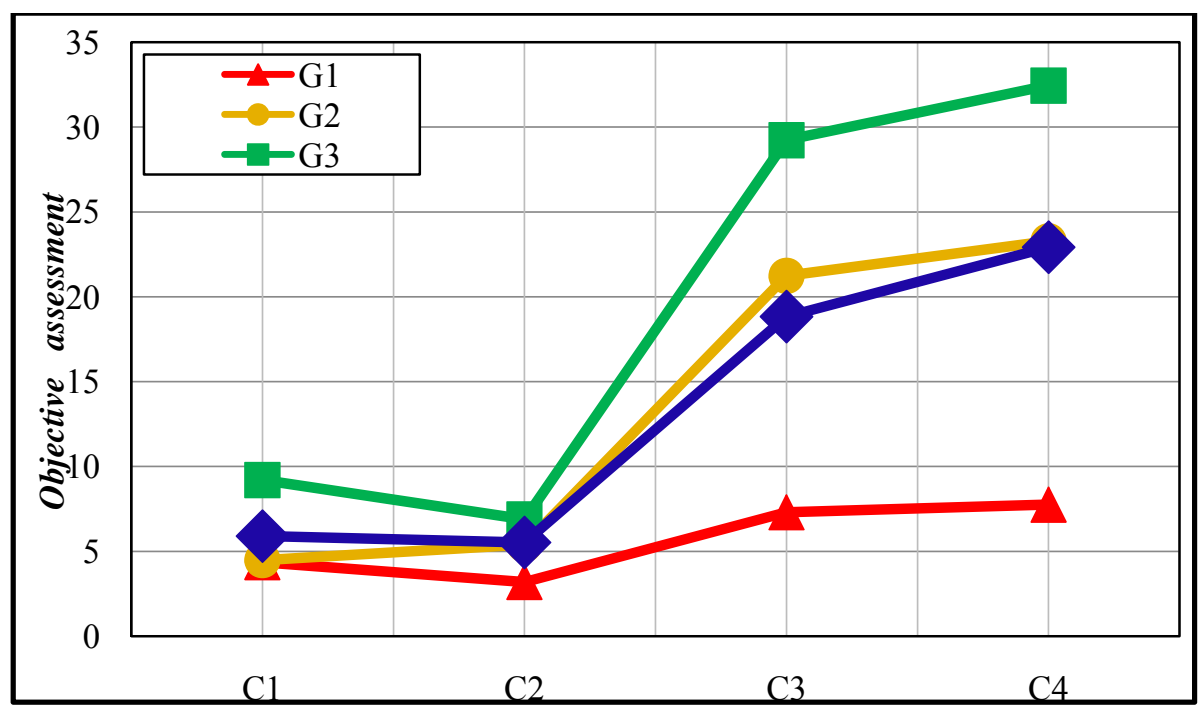

Fig. 12. Objective assessment for each group

\section{Analysis of conflictive criteria}

\section{a. Percentage of unemployment}

The group G3 (retirees) believe that the project will generate direct and indirect employment, as the hydrocarbon industry demands supplies that would increase the employment in all economic sectors. However, the group G1 (Primary activities population), in concordance with the groups G2 (university students) and G4 (specialists), strongly believe that the project will destroy the employment in sensitive sectors, such as tourism and fishing. Therefore, this fact generates discomfort on a part of the population in Valencia (see Fig. 13), as unemployment is a social problem in Spain, which increased since year 2009, due to the fact that the economic crisis in Europe and particularly in Spain impacts on the unemployment; for example, in Valencia in 2009 was $20.76 \%$, and in 2013 was $28.05 \%$ [31].

\section{b. GDP per capita}

The group G3 believe that the project will increase the GDP per capita, as there will be investment from the company that will impulse other sectors of the economy. However, for groups G1, G2 and G4, the project will affect to the more important economic sectors of Valencia, which are tourism and fishing. For example, a part of group G1, the fishing cooperative of Valencia strongly believes that the project will affect their economic income, considering the context of lack of employment (see Fig. 14). This fact could be understudied, asin the ComunitatVelenciana, the GDP per capita has been decreased according to increasing of economic crisis since 2009; for example, in 2009 was 20170 euros per year, and in 2013 was 19500 euros per year [31]. This is due to the fact that the employment and the salary have decreased notably.

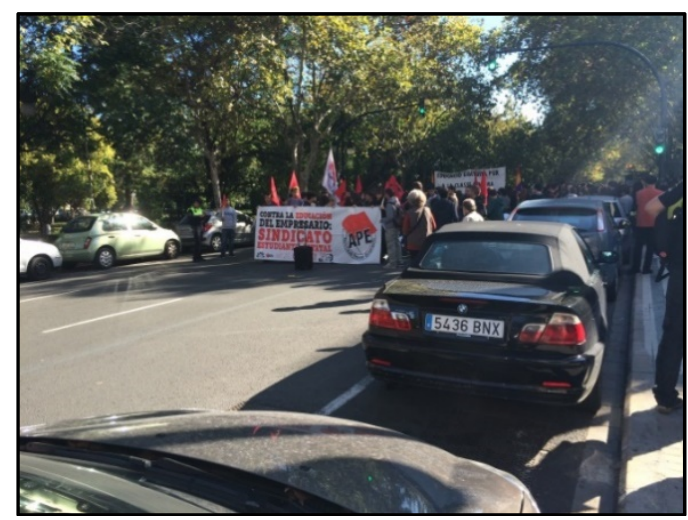

Fig. 13. Opposed citizens to the project

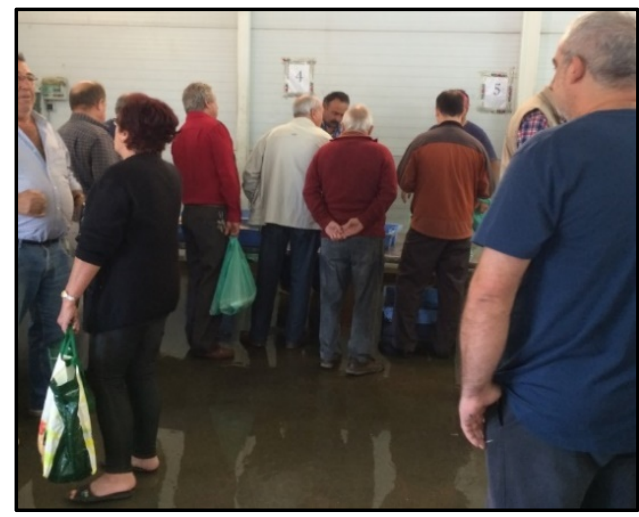

Fig. 14. Fishing cooperative of Valencia 


\section{CONCLUSIONS}

The methodology applied in this article made possible to integrate SIA and ECA. SIA was conducted by means the GC method, which quantified the qualitative information collected from stakeholder groups, and ECA was performed by means the EW method, which identified the controversial criteria. The results obtained on the hydrocarbon exploration project in the Sea of the Gulf of Valencia, Spain, could help to central government or authorities of the community to make the best decision to manage the use of the Gulf of Valencia.

The main advantages of the integrated method could be summarized as follows: the integrated method would be more effective than other classical multi-criteria methods, as it considers uncertainty within its analysis; would be more appropriate than other approaches based on fuzzy logic, as it considers clear extension of criteria within its analysis;and would have a lower cost than other statistical approaches during its application.

The main limitations of the integrated method could be summarized as follows: the approaches based on grey systems or Shannon entropy are not widely diffused compared to approaches based on multi-criteria analysis, fuzzy logic or statistics models; the Integrated method presents still subjective aspects, during information gathering and the establishment of limits of grey classes; and the calculations are still tedious during the application of the integrated method, this fact could be improved by implementing a computer system.

Finally, the integrated method could be applied, in future studies on social impact assessment and environmental conflict analyses, to other types of programs or projects. The number of stakeholder groups and criteria could be determinate according to each type of project or program and the concrete social situation of the zone of influence.

\section{REFERENCES}

[1] P. V Prenzel and F. Vanclay, "How social impact assessment can contribute to conflict management," Environ. Impact Assess. Rev., vol. 45, pp. 30-37, 2014.

[2] B. Tang, S. Wong, and M. C. Lau, "Social impact assessment and public participation in China: A case study of land requisition in Guangzhou," Environ. Impact Assess. Rev., vol. 28, no. 1, pp. 57-72, 2008.

[3] N. van der Voort and F. Vanclay, "Social impacts of earthquakes caused by gas extraction in the Province of Groningen, The Netherlands," Environ. Impact Assess. Rev., vol. 50, pp. 1-15, 2015.

[4] H. Wittmer, F. Rauschmayer, and B. Klauer, "How to select instruments for the resolution of environmental conflicts?," Land use policy, vol. 23, no. 1, pp. 1-9, 2006

[5] S. Liu and Y. Lin, Grey Systems: Theory and Applications. Berlin: Springer, 2010.

[6] L. N. Zhang, F. P. Wu, and P. Jia, "Grey Evaluation Model Based on Reformative Triangular Whitenization Weight Function and Its Application in Water Rights Allocation System,” Open Cybern. Syst. J., vol. 7, no. 1, pp. 1-10, 2013.

[7] Y. Zhang, J. Ni, J. Liu, and L. Jian, "Grey evaluation empirical study based on center-point triangular whitenization weight function of Jiangsu Province industrial technology innovation strategy alliance," Grey Syst. Theory Appl., vol. 4, no. 1, pp. 124-136, 2014.

[8] J. Deng, "Generation functions of grey systems," Fuzzy Math., vol. 5, no. 2, pp. 11-22, 1985.

[9] W.-H. Wu, C.-T. Lin, K.-H. Peng, and C.-C. Huang, "Applying hierarchical grey relation clustering analysis to geographical information systems - A case study of the hospitals in Taipei City," Expert Syst. Appl., vol. 39, no. 8, pp. 7247-7254, 2012.

[10] J. Yu, D. Wang, and H. Chengwu, "Selection method of monitoring parameter optimization in prognostics and health management based on grey clustering decision," Grey Syst. Theory Appl., vol. 3, no. 1, pp. 16-25, 2013.

[11] J. Cui, S. F. Liu, B. Zeng, and N. M. Xie, "A novel grey forecasting model and its optimization," Appl. Math. Model., vol. 37, no. 6, pp. 4399-4406, 2013.

[12] J. Wei, L. Zhou, F. Wang, and D. Wu, "Work safety evaluation in Mainland China using grey theory," Appl. Math. Model., vol. 39, no. 2, pp. 924-933, 2015.

[13] J. Yang, C. Ryan, and L. Zhang, "Social conflict in communities impacted by tourism," Tour. Manag., vol. 35, pp. 82-93, 2013.

[14] B. Bolin, T. Collins, and K. Darby, "Fate of the verde: Water, environmental conflict, and the politics of scale in Arizona's central highlands," Geoforum, vol. 39, no. 3, pp. 1494-1511, 2008.

[15] M. Saqalli, S. Thiriot, and F. Amblard, "Investigating social conflicts linked to water resources trhough agent-based modelling," NATO Sci. Peace Secur. Ser., vol. 75, pp. 142-157, 2010.

[16] C. E. Shannon and W. Weaver, The mathematical theory of communication. The University of Illinois Press: Urbana, 1947.

[17] M. Zeleny, Multiple criteria decision making. New York: Springer, 1996.

[18] B. Ainslie, C. Reuten, D. G. Steyn, N. D. Le, and J. V Zidek, "Application of an entropy-based Bayesian optimization technique to the redesign of an existing monitoring network for single air pollutants.," J. Environ. Manage., vol. 90, no. 8, pp. 2715-2729, 2009.

[19] L. Liu, J. Zhou, X. An, Y. Zhang, and L. Yang, "Using fuzzy theory and information entropy for water quality assessment in Three Gorges region, China,” Expert Syst. Appl., vol. 37, no. 3, pp. 2517-2521, 2010.

[20] A. Shemshadi, H. Shirazi, M. Toreihi, and M. J. Tarokh, "A fuzzy VIKOR method for supplier selection based on entropy measure for objective weighting,” Expert Syst. Appl., vol. 38, no. 10, pp. 12160-12167, 2011.

[21] H. H. Bafroui, A. Ohadi, H. Heidari Bafroui, and A. Ohadi, "Application of wavelet energy and Shannon entropy for feature extraction in gearbox fault detection under varying speed conditions," Neurocomputing, vol. 133, pp. 437-445, 2014.

[22] S. H. Hamilton, S. ElSawah, J. H. A. Guillaume, A. J. Jakeman, and S. A. Pierce, "Integrated assessment and modelling: Overview and synthesis of salient dimensions," Environ. Model. Softw., vol. 64, pp. 215-229, 2015.

[23] E. Arun, "Towards a shared systems model of stakeholders in environmental conflict," Int. Trans. Oper. Res., vol. 15, pp. 239-253, 2008.

[24] V. Luyet, R. Schlaepfer, M. B. Parlange, and A. Buttler, "A framework to implement Stakeholder participation in environmental projects," J. Environ. Manage., vol. 111, pp. 213-219, 2012.

[25] Environmental Resources Management Iberia, Documento Ambiental para la Campaña de Adquisición Sísmica 3D en los Permisos B, G, AM-1 y AM-2 en el Golfo de Valencia. Madrid; España: ERM Iberia, S.A., 2012.

[26] A. Delgado and I. Romero, "Environmental conflict analysis using an integrated grey clustering and entropy-weight method: A case study of a mining project in Peru," Environ. Model. Softw., vol. 77, pp. 108-121, 2016. 
[27] E. O. Fagbote, E. O. Olanipekun, and H. S. Uyi, "Water quality index of the ground water of bitumen deposit impacted farm settlements using entropy weighted method,” Int. J. Environ. Sci. Technol., vol. 11, no. 1, pp. 127-138, 2014.

[28] Y. Ji, G. H. Huang, and W. Sun, "Risk assessment of hydropower stations through an integrated fuzzy entropy-weight multiple criteria decision making method: A case study of the Xiangxi River," Expert Syst. Appl., vol. 42, pp. 5380-5389, 2015.

[29] Z. Chang, Z. Qisen, C. Zheng, and Q. Zhang, "The assessment of the social, economic, and environmental impacts of expressway construction projects based on the DFGF Algorithm,' in Management and Service Science. MASS '09. International Conference, 2009, pp. $1-5$.

[30] P. Corbetta, Metodología y técnicas de investigación social. Madrid: McGRAW-HILL, 2007.

[31] INE-España, "Instituto Nacional de Estadística de España," 2014. [Online]. Available: http://www.ine.es/. [Accessed: 15-Jun-2014].

[32] Datos Macro, "Evolución anual PIB per capita Comunidad Valenciana," 2014. [Online]. Available: http://www.datosmacro.com/pib/espana-comunidades-utonomas/valencia. [Accessed: 30-Jun-2014].

[33] J. Aznar and F. Guijarro, Nuevos métodos de valoración, modelos multicriterio, vol. 2a. Valencia: Universitat Politèctica de València, 2012.

[34] J. Landeta, El método Delphi, Una técnica de previsión del futuro. Barcelona, España: Editorial Ariel, 2002.

[35] V. Campos-Climent, A. Apetrei, and R. Chaves-Ávila, "Delphi method applied to horticultural cooperatives," Manag. Decis., vol. 50, no. 7, pp. 1266-1284, 2012

[36] T. L. Saaty, "The Analytic Hierarchy Process," McGraw-Hill, New York, 1980.

[37] M. Sadeghi and A. Ameli, "An AHP decision making model for optimal allocation of energy subsidy among socio-economic subsectors in Iran," Energy Policy, vol. 45, pp. 24-32, 2012.

[38] A. Baykasoğlu and İ. Gölcük, "Development of a novel multiple-attribute decision making model via fuzzy cognitive maps and hierarchical fuzzy TOPSIS,” Inf. Sci. (Ny)., vol. 301, pp. 75-98, 2015.

[39] B. D. Rouyendegh and T. E. Erkan, "Selection of academic staff using the fuzzy analytic hierarchy process (FAHP): a pilot study," Tech. Gaz., vol. 199, no. 4, pp. 923-929, 2012.

[40] A. Augustsson, M. Filipsson, T. Öberg, and B. Bergbäck, "Climate change - An uncertainty factor in risk analysis of contaminated land," Sci. Total Environ., vol. 409, no. 22, pp. 4693-4700, 2011.

[41] L. Zadeh, "Fuzzy sets," Inf. Control, vol. 8, no. 3, pp. 338-353, 1965.

\section{AUTHOR PROFILE}

Alexi Delgado, $\mathrm{PhD}$, received his $\mathrm{PhD}$ degree on water and environmental engineering at the Polytechnic University of Valencia, Spain. He performed a stay at the Adam Mickiewicz University in Poznan, Poland, in 2015. He earned his Master degree on Mining and Environment at the National University of Engineering, Lima-Peru. In addition, he has published articles in the fields of environmental management and tools for environmental impact assessment and social impact assessment.

Dr I. Romero is a Professor of the department of water and environment engineering at the Polytechnic University of Valencia, Spain. She received her PhD on water and environmental engineering at the Polytechnic University of Valencia, Spain. Her research interest focus is on environmental impact assessment; she has published articles and books in this topic. 